\title{
The Impact of IFRS Adoption on Accounting Conservatism in the European Union
}

\author{
Daniel Zeghal (Corresponding author) \\ Professor of accounting, Telfer School of Management \\ University of Ottawa, 55 Laurier East \\ Ottawa, ON, K1N 6N5, Canada \\ Email: zeghal@telfer.uOttawa.ca
}

\begin{abstract}
Zouhour Lahmar
Research Associate, CPA-Canada Accounting and Governance Research Center University of Ottawa
\end{abstract}

Email: Zouhourlahmar@gmail.com

Received: March 28, 2016 Accepted: April 14, 2016 Published: June 10, 2016

doi:10.5296/ijafr.v6i1.9581 URL: http://dx.doi.org/10.5296/ijafr.v6i1.9581

\begin{abstract}
Purpose -The purpose of this study is to analyze mandatory IFRS adoption's impact on accounting conservatism.

Design/methodology/approach - Our empirical study is conducted on a sample of 15 European countries, observed from the year 2000 to 2010. We analyze both conditional and unconditional conservatism, which we measured, respectively, by timely bad news recognition as compared to recognition of good news and discretionary accruals.

Findings - The results of the empirical study confirm a significant reduction of accounting conservatism in the IFRS adoption period. This reduction is affected by the accounting model prevailing in a particular country. Moreover, the study shows a reduction of the gap between the two accounting models in the post-IFRS adoption period.

Practical implications - The results obtained would be relevant for many decision makers such as investors, standard setters, IASB, European Union countries as well as those wishing to adopt International Standards.
\end{abstract}

Originality/value - Our study complements and enriches the existent literature about the 
impact of the International Standards adoption. It dresses an important issue in a relatively long period to better assess the impact of IFRS.

Keywords: IFRS, conditional conservatism, unconditional conservatism, European Union, Accounting model.

\section{Introduction}

Conservatism has always been recognized as one of the most important principals in accounting. There has been a general consensus between accounting regulators and preparers of accounting reports that conservatism is an attractive characteristic of accounting information particularly relevant to many decision makers. The adoption in the last decade of the International Financial reporting Standard (IFRS) by a large number of countries has brought the issue of accounting conservatism to the limelight of professionals and academics in accounting.

IFRS are characterized by the adoption of a particular decision-making approach along with the prospective orientation of the information presented which allows investors to make a fair evaluation of this information. Indeed, the relevance of the information and its reliability are key in facilitating the decision-making processes of investors. Thus, the prudence principal is not as important as countries operating under the continental accounting model predicted it would be. Although the International Accounting Standards Board (IASB) advocates the use of prudence in cases of uncertainty, it also confirms that it is not a necessary qualitative characteristic. However, conservatism has always played a leading role in accounting practices. Indeed, the fact that it has often been recognized as a basic principle for accounting practice has influenced accounting theory (Basu1997).

Studies conducted in different countries showed that the accounting conservatism level varies from one context to another (Giner and Rees 2001; Lara and Mora 2004; Grambovas, Giner and Christodoulou 2006; Ferreira, Lara and Gonçalves2007, among others).This is not altogether surprising since most of the research studies confirmed the existence of differences between accounting practices around the world. This encouraged some of the researchers to analyze IASB's position as an international accounting harmonization body. D'Arcy (2001) mentions that preparing the financial information with reference to IASB is clearly dominated by the Anglo-American approach. Lewis and Salter (2006) similarly showed that IFRS are also closer to American standards. Hung and Subramanyam (2007) analyzed the characteristics of the International Accounting Standards (IAS) and compared them to German standards. These authors specify that the international approach is oriented towards the capital market and investors' needs and this constitutes an Anglo-American characteristic. Similarly, they add that IFRS will focus on the assessment of balance sheet items at fair value unlike the German position, which they took to represent the continental model in their study and which is based on the principle of prudence and the smoothing of results. This idea has already been spelled out by Dumontier and Raffournier (2005) who find that it can be considered as an Anglo-American characteristic. 


\section{MInstitute ${ }_{\text {Mink }}^{\text {Macrothink }}$}

International Journal of Accounting and Financial Reporting ISSN 2162-3082 2016, Vol. 6, No. 1

In order to analyze the impact of this international bias towards the accounting practices of the countries operating under the continental model, we would like to examine the effect of applying IFRS in countries belonging to the European Union, with reference to the 1606/2002 regulation of the European Parliament. The objective of this research is to verify the hypothesis claiming that the adoption of the International Accounting Standards can affect the conservatism level of the financial statements of companies from the European Union. More specifically, we address the following research question: What is the impact of mandatory IFRS adoption in Europe on the level of accounting conservatism? The results of our study would be relevant for many decision makers such as investors, standard setters, IASB, European Union countries as well as those wishing to adopt International Standards and would explain different consequences that can result from adopting IFRS.

The remainder of the paper is organized as following: the second section is focused on IFRS, their characteristics and their adoption. The third one discusses the concept of accounting conservatism and its theoretical foundations. The fourth section states the research objective and develops the hypotheses. The fifth section presents our methodology. In the sixth section we present the results of our empirical analysis. Finally, the conclusion and suggestions for future research will be the subject of our last section.

\section{IFRS, Their Characteristics and Their Adoption}

Thanks to IASB's achievements and to its high quality standards, IFRS are either required or authorized in 113 countries (Ball 2006; Heidi 2009). Similarly, international bodies encourage the harmonization process conducted by the IASB and also the adoption of IFRS. On July 19, 2002,the European Council approved the 1606/2002 regulation that imposes on European companies the requirement that they prepare their financial statements according to IFRS. This decision concerns consolidated accounts from January 1,2005.

IFRS are presumed to produce high quality information which leads to the reduction of the information asymmetry between managers and external users of the financial information (Daske 2006; Ball 2006; Gassen, Fülbier and Sellhorn 2006; Soderstrom and Sun 2007). In the same context, Ball (2006) specifies that IFRS produce more precise, better understandable and more appropriate financial information than local accounting standards. In addition to the characteristics of the institutional environment and the company's commitment, Gassen et al. (2006) notice a new factor that influences the financial information quality considering standards quality. The use of a unique body to prepare financial information improves its comparability and, thus, favors better decision making for investors especially (Soderstrom and Sun 2007; Daske 2006; Daske and Gebhardt 2006). In the European context, International Standards are presumed to contribute positively to improving the financial information's quality when compared to local standards in this area. Indeed, International standards are more demanding in terms of mandatory disclosure considering the quantity of the communicated information as well as their informational content (Daske 2006; Daske and Gebhardt, 2006). Thus, as a result of the IFRS application, Daske and Gebhardt's study (2006)has shown that the quality of the information communicated by the sampled firms has significantly improved. 
Although the benefits of adopting international standards are well recognized, many researchers have identified the presence of various difficulties hindering the convergence process of national accounting standards towards international ones (Larson and Street, 2004; Jermakowicz and Tomaszewski 2006; Moris,Gray, Pickering and Aisbitt2014). For example, in countries where capital markets are not sufficiently developed, IFRS application can be hampered. In addition, IAS-IFRS are generally considered as standards for multinational groups. Similarly, some transactions are considered as quite complicated and specific to countries with developed economies (Larson and Street 2004).In Australia, Moris et al. (2014) recently studied the issue of the benefits and difficulties of implementing IFRS in that country using a questionnaire comprising 17 questions which was sent to the financial directors of 1666 listed companies. The results of this study have shown that the responders principally care about the difficulties faced when applying some of these treatments as well asthe high cost of implementing standards while they find that benefits in capital markets are still limited.

\section{The Concept of Accounting Conservatism and Its Foundations}

Sterling (1967) considers accounting conservatism to be the oldest principle that has influenced accounting practices. Basu (1997) has proposed a definition that refers to the required verification for taking into account gains and losses. In fact, it appears that accountants require a higher verification level for recognizing good news as opposed to bad. In this context, the author concluded that income reflects bad news more quickly than good. The conservatism definitionas the undervaluation of income and assets aims to protect creditors (Nobes and Parker 2008). Basu's definition (1997) favors shareholders' interests and seeks to ensure their protection since they require timely information, especially when it concerns bad news, in order to make their decisions (Lara and Mora 2004).

Gray (1988) identified conservatism as one of the four accounting values ${ }^{1}$. He considers it as "the value that prefers a conservative measurement approach dealing with the uncertainty associated with future events, in opposition to an optimistic approach of laissez-faire and risk taking". Basu (1997) considered that accounting conservatism plays an effective role in the realization of concluded contracts between the company and different parties.

Watts (2003) considers conservative accounting practices as an effective mechanism to prepare financial information. Indeed, accounting conservatism leads to reliable financial information since it requires a higher control level thus a minimal error risk. Moreover, conservatism has often been used as a quality measure for financial information (Francis,Lafond, Olsson and Schipper 2004; Cheng and Liu 2007). Byungcherl (2012) studied the implications of accounting conservatism on the accuracy of forecasts presented by financial analysts. He conducted his study on listed companies on NYSE, AMEX and

\footnotetext{
${ }^{1}$ According to Gray (1988), there are four accounting values:

- Professional judgment versus regulation control.

- Uniformity versus flexibility.

Conservatism versus optimism.

Discretion versus transparency
} 
NASDAQ. The data collected are related to the period from 1979 to 2008. Byungcherl (2012) found that financial analysts incorporate accounting conservatism in forecasting companies' results. Moreover, they face more difficulties while estimating the results of less conservative companies.

Furthermore, in order to analyze the determinants of accounting conservatism, some authors have proposed that managers and auditors prefer conservative practices to avoid legal prosecutions and related costs (Kothari,Lys, Smith and Watts 1988; Mensah, Considine and Oakes 1994; Watts 2003).Watts (2003 a), sees that the more a firm realizes positive results, the more it uses accounting conservatism in order to reduce the amount of tax payable.

Regulation was also analyzed as directly or indirectly influencing the accounting conservatism level. Thus, accounting standards require a certain level of caution while preparing financial statements in order to control the exaggerated optimism of managers (Sterling 1967, Grambovas et al. 2006). Lang,Raedy and Yetman (2003) think that listed companies in the USA are subjected to more pressure regarding the quality of information they communicate. They demonstrate a higher conservatism level for listed companies in the USA. In the same context, Lobo and Zhou (2006) have analyzed accounting conservatism before and after the enactment of the $\mathrm{SOX}^{2}$ law. They have noted an increase in the accounting conservatism level after the application of this law.

\section{Research objective and hypothesis development}

\subsection{Review Of Previous Studies:}

Adopting IFRS is an important decision that significantly impacts accounting practices. Indeed, numerous differences exist between these standards and the local ones of many countries especially in Europe. Hung and Subramanyam (2007) conducted a study on a sample of 80 German companies that have voluntarily adopted these standards from 1998 to 2002. Theauthors specify that German standards are dominated and influenced by tax and prudence, while the international standards are independent from tax rules and advocate for a fair value evaluation. Further to that, Prather-Kinsey, Jermakowicz and Vongphanith (2008) have examined the relevance and the informational content of published results by 157 European companies which adopted IFRS for the first time in 2005. In both these studies the authors consider that the IFRS adoption provides several different advantages especially for investors. Indeed, there is a reduction in capital cost, an improvement of the informational content and of the relevance of information prepared in accordance with IFRS. However, the authors notice that these variations are more significant in companies from countries operating under a continental legal system. Thus, they conclude that accounting standards applied by countries operating under the Anglo-American model are closer to International Standards than those of countries operating under the continental model.

Considering the quality of financial statements measured by discretionary accruals, Zeghal, et al. (2011) analyzed the impact of mandatory IFRS adoption on results management in French

\footnotetext{
${ }^{2}$ The Sarbanes-Oxley Act is the law on the accounting reform for listed companies and the protection of promulgated investors on July, 312002 in United States of America.
} 


\section{Mll Macrothink}

International Journal of Accounting and Financial Reporting ISSN 2162-3082 2016, Vol. 6, No. 1

companies. In a sample of 851 French listed companies, the analysis shows a decrease in discretionary accruals after adopting IFRS. Therefore, they have concluded that adopting IFRS reduces results management in French companies. Focusing on accounting conservatism, Piot et al. (2010) conducted their study over the period from 2001 to 2008. They considered early, in time and late IFRS adopters and found a decrease of conditional conservatism and an increase of unconditional conservatism. The authors concluded that mandatory IFRS adoption impeded accounting quality. Staying in the European context, Zeghal et al.(2012) have discussed the issue of mandatory IFRS adoption and its impact on the quality of companies' results. The analysis of 1547 companies from 15 European Union countries from 2002 to 2007, confirms the hypothesis of improving the quality of results after IFRS adoption. However, Zeghal et al. (2012) have shown that there is a reduction in timeliness, in the conditional conservatism level and the relevance of the information after the mandatory IFRS adoption. More recently, Anwer et al. (2013) also addressed the question of mandatory IFRS adoption and its impact on accounting quality. They employed the timeliness of loss recognition as a proxy for reporting aggressiveness. The results of their study show a decrease in the timeliness of loss recognition after the switch to IFRS. This finding contradicts the results of Zhuang et al.(2013) which showed that IFRS have no impact on accounting conservatism. The results of Zhuang et al.(2013) can be explained by their approach which, according to the authors, allows overcoming the inter-temporal limitations. They focused on the period 2005-2008 and compared the degree of conditional conservatism under IFRS versus local GAAP. However André et al. (2015) confirmed a decrease in conditional conservatism in the post mandatory IFRS adoption. The authors state that this reduction is more significant for countries with low audit environment and weak enforcement of compliance.

According to these studies, the issue of the consequences of IFRS adoption on accounting conservatism is still open for debate. Our objective is to palliate to some limitations of previous studies, including short periods of study, measures of accounting conservatism and samples considered, in order to bring a more comprehensive and a more convincing response to the question of IFRS adoption on accounting conservatism. Our study differs from previous ones in several important respects. First, we use a longer period especially after IFRS adoption which is likely to allow a better analysis of the consequences of these standards. Second, previous studies that compared different contexts were not able to distinguish the effects of IFRS adoption from the effects of other specific events. As a remedy for the existing differences in results, we made sure to analyze a relatively homogeneous group. In fact, the European Union, when it was first set up, insisted on the establishment of an economic and monetary union through harmonizing the inflation rate, the monetary unit (Euro), the treatment of the public debt and the budget deficit (Lara and Mora 2004). Third, two different measures of conservatism are considered in order to control for measure biases and to take the two forms of conservatism.

\subsection{The Research Objective And Hypotheses To Be Tested:}

The objective of this research is to analyze the impact of adopting IFRS on the accounting conservatism level of European Union countries. Recent studies (Ahmed A. et al. 2013; 


\section{MInstitute Macrothin $^{m}$}

International Journal of Accounting and Financial Reporting ISSN 2162-3082

Zhuang Z. et al. 2013 and André P. et al. 2015) examined accounting conservatism after mandatory IFRS adoption and found different results. We believe that the impact of IFRS on accounting practices needs more investigation in a relatively longer period. Similarly, we think that conservatism, as a fundamental accounting principle, requires further studies especially in accordance with the IFRS application. Thus, the present study is conducted from 2000 to 2010 in 15 European Union countries attempting to test the impact of IFRS after five years of their adoption. Moreover, we consider two conservatism measures in order to reflect the two forms usually used in empirical researches. More specifically, it would be interesting to analyze the growing conservatism level before and after the IFRS application by answering the following questions: Are there any differences between both forms of conservatism? Is the impact of IFRS on conservatism identical for countries operating under a continental model as it is for those operating under the Anglo-American model? Our research discusses these issues and tries to find the appropriate answers through testing hypotheses that are formulated below.

\subsection{Accounting Conservative Practices And Differences Between Both Accounting Models:}

Previous studies on accounting conservatism have generally confirmed the application of this principle but some differences were noted with regard to the difference in extent from one country or group of countries to another (Gray 1980; Basu 1997; Ball, Kothari and Robin 2000; Giner and Rees 2001; Lara and Mora 2004; Grambovas et al. 2006). Gray (1980) has developed a conservatism index ${ }^{3}$ in order to compare the application of this principle in France, Germany, and Great Britain. The collected results of this study show a difference in the conservatism level among the chosen sample. Great Britain presents a lower conservatism level than France and Germany. Nobes and Parker (2008) notice that continental Europe is characterized by the highest conservatism level. For example, both authors report that the equity value of Volkswagen under IFRS is twice its calculated equity under German standards.

The high conservatism level of countries operating under the continental model reflects the priorities of this system. Thus, the legal approach that prevails with respect to accounting practices in these countries encourages accountants to adopt conservative accounting methods in order to primarily protect creditors' interest. Based on this logic and previous research, we expect a higher conservatism level in countries operating under the continental model. Thus, we formulate the two following hypotheses:

H1a: Unconditional conservatism is higher in countries operating under the continental model than in those operating under the Anglo-American model.

H 1b: Conditional conservatism is higher in countries operating under the continental model than in those operating under the Anglo-American model.

${ }^{3}$ It is calculated as following: $1-\left[\frac{R_{A}-R_{D}}{\left|R_{A}\right|}\right]$; with $\mathrm{R}_{\mathrm{A}}=$ Adjusted profitand $\mathrm{R}_{\mathrm{D}}=$ disclosed profit. 
4.4. The Impact Of Adopting International Standards On The Accounting Conservatism Level

Ball et al. (2000), state that the standards of the IASB are closer to the Anglo-American standards than to those adopted by countries operating under the continental model. Indeed, D'Arcy (2001) confirms this idea and considers that the philosophy dominating IFRS is different from the European directives' philosophy. It seems that the impact of applying IFRS would be less significant in countries where standards are already under the Anglo-American influence. In this context, Zeghal et al. (2012) mentioned that conservatism decreased following the mandatory IFRS adoption. They also found that the decrease in the conservatism level after adopting IFRS is more important for countries with local standards different from international ones.

Based on the previous observations, we expect a decrease in the accounting conservatism level after the IFRS adoption. The expected decrease in the conservatism level after the introduction of IFRS could be explained by the destination of the financial information which represents an important characteristic of IFRS. Indeed, as previously explained, countries operating under the continental model seek to principally satisfy the financial information needs of governments and creditors since they both care about the solvency and the sustainability of the company. However, the international financial information's objective is to primarily satisfy the needs of investors who care about the company's performance and the profitability of their investments. Thus, unconditional conservatism better serves the accounting objective of the continental model than the Anglo-American one does. Therefore, we formulate the two following assumptions:

\section{H2a: IFRS adoption in European Union countries reduces the unconditional conservatism level.}

H2b: IFRS adoption in European Union countries reduces the conditional conservatism level.

From previous observations, on the one hand, we expected a decrease in the conservatism level because of the IFRS application. On the other hand, we have stated that International Standards are similar to the characteristics of the Anglo-American model. Therefore, the impact of the IFRS adoption is expected to be more apparent when these standards are applied in countries operating under the continental model. At this level, the assumption is formulated as follows:

$H$ 3a: The decrease in the unconditional conservatism level is more important in countries operating under the continental model.

H 3b: The decrease in the conditional conservatism level is more important in countries operating under the continental model.

Furthermore, the decrease in the conservatism gap due to the IFRS adoption in European Union countries should to be examined. In fact, we have considered that the conservatism level is higher in countries operating under a continental model and it will decrease after this adoption. We expect that this will diminish the conservatism gap between the continental 
model and the Anglo-American one. For that, the following hypothesis is formulated:

\section{H 3c: IFRS adoption reduces the conservatism gap between the two accounting models.}

\section{Research Methodology}

\subsection{Sample And Data Collection Procedure}

Our research is based on a sample of 15European countries. In this study we will analyze the impact of the mandatory IFRS adoption on accounting conservatism. The selected companies applied these standards for the first time in 2005 following the described 1606/2002 regulation. Thus, to be part of our chosen sample, these companies must:

- Be listed : since the mandatory IFRS adoption by European Union countries concerns consolidated financial statements of listed companies

- Have the necessary data for at least two years for each period before and after the mandatory adoption in $2005^{4}$.

As a result, all companies that proceeded to an earlier IFRS adoption, before 2005, were excluded. As with previous studies (Giner and Rees 2001; Lara and Mora 2004), financial firms such as banks, insurance companies, investment and leasing companies (code SIC 6069), are not included in the sample because of their difference with respect to other companies regarding the applied rules and procedures. Also, to facilitate the identification of the IFRS adoption year, we have excluded companies with a closure date different from the calendar year.

The list of companies from our sampled countries is obtained from the World scope database. Thereafter, data related to these companies have been collected from the "Thomson Reuters Eikon" database.

The final sample of our study is composed of 1216 (1126) companies for the sample measuring conditional (unconditional) conservatism. The selection procedure is described in table 1. The analysis will be conducted over five years before and five years after the mandatory adoption. However, we will not consider 2005 since it is the adoption year and it could distort our results. Similarly, the year 2008 will not be considered in order to eliminate any effects of the financial crisis which may affect data reliability especially stock market data in this year. Considering both facts, our study is conducted in two sub-periods; the first, from 2000 to 2004, representing the period before the adoption while the second, from 2006 to 2007 and from 2009 to 2010, considers the period after the adoption. All data are expressed in Euros and we proceeded to their winsorization at 1 percent in order to take into account the outliers.

${ }^{4} \mathrm{He}$ et al. (2008) estimate that this period is sufficient to make the analysis. 
Table 1: The sample construction process

\begin{tabular}{|l|l|l|}
\hline Description & \multicolumn{2}{l|}{ Number } \\
\hline & $\begin{array}{l}\text { Conditional } \\
\text { conservatism }\end{array}$ & $\begin{array}{l}\text { Unconditional } \\
\text { conservatism }\end{array}$ \\
\hline Starting Population & 6026 & 6026 \\
\hline $\begin{array}{l}\text { Exclusion of companies with a closing date of the accounting period different } \\
\text { from December } 31 \text { and companies that do not meet the selection criteria }\end{array}$ & 4080 & 4080 \\
\hline Exclusion of companies from the financial sector & 399 & 399 \\
\hline Subtotal 1 & 1547 & 1547 \\
\hline Companies lacking data for at least 2 years after and before IFRS adoption & 331 & 421 \\
\hline FINAL SAMPLE & 1216 & 1126 \\
\hline
\end{tabular}

\subsection{Characteristics of The Sampled Countries}

The sample is composed of two groups: the first represents the continental model and the second the Anglo-American one. Similarly, we will take account of the activity sector of each company from the sample through their classification according to SIC codes. Table 2 summarizes the list of companies from the sample divided according to the accounting model (Panel A) and the activity sector (Panel B). From this table, we note that the sample is composed of 1216 companies for the conditional conservatism (CC) sample and 1126 for the unconditional conservatism (UC) sample. In the CC (UC), 233(226) companies for the subsample of the Anglo-American model, versus 983 (902) companies for the continental model. The number of companies varies from two, in Luxembourg, to 271 (297) in France. France is the most represented country in the sample with 22.29 (26.38)percent followed by United Kingdom with 12.91 (14.74)percent, Sweden is in third place with 11.84 (13.23)percent. Luxembourg is ranked last with two companies. Considering the activity sector distribution, panel B from table 2 shows that the industry sector is the most represented in our sample with a percentage of 47.70 (47.16)percent. Service sectors with 21.22 (22.20)percent and public service with 9.70 (10.57) percent respectively take the second and third places. The public administrative sector occupies the last rank with only one (two)companies. 
Table 2: Sample distribution by countries and activity sectors

\begin{tabular}{|c|c|c|}
\hline Countries & \multicolumn{2}{|c|}{ Number of companies (percentage) } \\
\hline \multicolumn{3}{|l|}{ Continental model } \\
\hline & Sub-sample $1^{5}$ & Sub-sample $2^{6}$ \\
\hline France & $271(22.29)$ & $297(26.38)$ \\
\hline Sweden & $144(11.84)$ & $149(13.23)$ \\
\hline Greece & $137(11.27)$ & $16(1.42)$ \\
\hline Italy & $115(9.46)$ & $129(11.46)$ \\
\hline Germany & $85(6.99)$ & $99(8.79)$ \\
\hline Finland & $65(5.35)$ & $40(3.55)$ \\
\hline Spain & $60(4.93)$ & $56(4.97)$ \\
\hline Belgium & $38(3.31)$ & $41(3.65)$ \\
\hline Denmark & $33(2.71)$ & $38(3.37)$ \\
\hline Portugal & $28(2.30)$ & $29(2.58)$ \\
\hline Austria & $5(0.41)$ & $6(0.53)$ \\
\hline Luxembourg & $2(0.16)$ & $2(0.18)$ \\
\hline Sub total & $983(80.84)$ & $902(80.11)$ \\
\hline \multicolumn{3}{|c|}{ Anglo-american model } \\
\hline & Sub-sample 1 & Sub-sample 2 \\
\hline UK & $157(12.91)$ & $166(14.74)$ \\
\hline Netherlands & $60(4.93)$ & $41(3.64)$ \\
\hline Ireland & $16(1.32)$ & $17(1.51)$ \\
\hline Sub total & $233(19.16)$ & $224(19.89)$ \\
\hline GENERAL TOTAL & 1216 & 1126 \\
\hline
\end{tabular}

\footnotetext{
${ }^{5}$ Sub-sample 1 is the group of countries representing the continental model.

${ }^{6}$ Sub-sample 2 is the group of countries representing the Anglo-Saxon model.
} 
Panel B : The distribution of the sampled companies by activity sector

\begin{tabular}{|l|l|l|l|}
\hline Sector & SIC Code & \multicolumn{2}{l|}{ Number of companies (Percentage) } \\
\hline & & Sub-sample & Sub-sample 2 \\
\hline Industry & $20-39$ & $580(47.70)$ & $531(47.16)$ \\
\hline Services & $70-89$ & $258(21.22)$ & $250(22.20)$ \\
\hline Public services & $40-49$ & $118(9.70)$ & $119(10.57)$ \\
\hline Wholesale trade & $50-51$ & $107(8.80)$ & $88(7.82)$ \\
\hline Construction & $15-17$ & $60(4.93)$ & $50(4.44)$ \\
\hline Retail trade & $52-59$ & $51(4.20)$ & $48(4.26)$ \\
\hline Mines & $10-14$ & $33(2.71)$ & $32(2.84)$ \\
\hline Agriculture, forestry and fishing & $01-09$ & $8(0.66)$ & $6(0.53)$ \\
\hline Public administration & $90-99$ & $1(0.08)$ & $2(0.18)$ \\
\hline General TOTAL & & 1216 & 1126 \\
\hline
\end{tabular}

\subsection{Conservatism Measure And Studied Variables}

The accounting literature distinguishes between unconditional conservatism and the conditional one (Ball and Shivakumar 2005; Beaver and Ryan 2005; Qiang 2007). Obviously, both forms were considered as two different measures since they are not similarly defined. The first is often related to practices aiming to undervalue assets and/ or overstate liabilities. The second is rather related to the recognition of economic losses incurred by the company.

\subsubsection{The Unconditional Conservatism Measure}

The term « unconditional » is used to emphasize that this conservatism form does not depend on good or bad news. Similarly to previous studies (Lobo and Zhou 2006; Anwer and Duellman 2007; He, El-Masry and Wu 2008), we use discretionary accruals as a measure of this form with reference to Jones model modified by Dechow, Sloan and Sweeny (1995). Total accruals (TAC) are the difference between net results (NR) of the company and its operating cash flows (OCF). The first step of the discretionary accruals level estimation consists of estimating the total accruals level, TAC, similarly to the modified Jones model. We estimate the model (1.1) below each year for each two-digit SIC industry to ensure the observations homogeneity. Discretionary accruals are represented by the residue of the model 1.1 (He et al. 2008). This model is presented as follows:

$\operatorname{TAC}_{\mathrm{i}, \mathrm{t}}=\square_{1}+\square_{2}\left(\Delta \mathrm{REV}_{\mathrm{i}, \mathrm{t}}-\Delta \mathbf{R E C}_{\mathrm{i}, \mathrm{t}}\right)+\square_{3} \mathbf{P P E}_{\mathrm{i}, \mathrm{t}}+\varepsilon_{\mathrm{i}, \mathrm{t}}$ 


\section{Mll Macrothink}

International Journal of Accounting and Financial Reporting

ISSN 2162-3082

2016, Vol. 6, No. 1

$\mathrm{TAC}=$ Total Accruals; $\triangle \mathrm{REV}=$ Change in revenues; $\triangle \mathrm{REC}=$ Change in receivables; $\mathrm{PPE}_{\mathrm{it}}=$ Gross property plant and equipment. All variables are scaled by lagged total assets.

Once discretionary accruals are estimated, they will be regressed, as shown in table 3 below on the different variables of the study in order to test the formulated assumptions.

\subsubsection{The Conditional Conservatism Measure}

The literature has shown a strong appeal to the model developed by Basu (1997) as a reference model to measure conditional conservatism in the European or other contexts (Lara and Mora 2004; Lobo and Zhou 2006; Grambovas et al. 2006; Gassen et al. 2006; He et al. 2008). It reflects accountants' tendency to require more verification when considering good news. Despite some critics(Givoly D., C. Hayn et A. Natarajan, 2007), the Basu's modelis still considered one of the most appropriate measures of asymmetric timeliness in bad news incorporation (Piot C. et al. 2010). Basu'smodel (1997) is presented as follows:

$\mathbf{N I}_{i t}=\beta_{0}+\beta_{1} \mathbf{R N}_{\mathrm{it}}+\boldsymbol{\beta}_{2} \mathbf{R}_{\mathrm{it}}+\boldsymbol{\beta}_{3} \mathbf{R N}_{\mathrm{it}} * \mathbf{R}_{\mathrm{it}}+\varepsilon_{\mathrm{it}}$

Where NI: Net income before extraordinary items per share deflated by share price at the beginning of the period; R: Rate of return of the firm ${ }^{7}$; RN: Dummy variable $=1$ in case of a negative rate of return and 0 in case of a positive rate of return; $\varepsilon=$ error term.

According toBasu (1997), when accounting practices are conservative, benefits include bad news being learned more rapidly than good news. The news are measured by the stock return between March of the current year and March from the next year.

Table 3: Synthesis of the selected empirical models

\begin{tabular}{|c|c|c|}
\hline Hypothesis & Model to estimate & Expectatio \\
\hline \multicolumn{3}{|c|}{ UNCONDITIONAL CONSERVATISM } \\
\hline H 1.a & $\mathrm{TDA}=\beta_{0}+\beta_{1} \mathrm{ACM}+\beta_{2} \mathrm{TA}+\beta_{3} \mathrm{DR}+\beta_{4} \mathrm{SG}+\beta_{5} \mathrm{CFO}+\varepsilon(1.2)$ & $\beta_{1}>0$ \\
\hline $\mathrm{H} 2 . \mathrm{a}$ & $\mathrm{TDA}=\beta_{0}+\beta_{1} \mathrm{IERS}+\beta_{2} \mathrm{TA}+\beta_{3} \mathrm{DR}+\beta_{4} \mathrm{SG}+\beta_{5} \mathrm{CFO}+\varepsilon(1.3)$ & $B_{1}>0$ \\
\hline $\mathrm{H} 3 . \mathrm{a}$ & $\mathrm{TDA}=\beta_{0}+\beta_{1} \mathrm{IFRS}+\beta_{2} \mathrm{TA}+\beta_{3} \mathrm{DR}+\beta_{4} \mathrm{SG}+\beta_{5} \mathrm{CFO}+\varepsilon$ & $\beta_{1 C}>\beta_{14}{ }^{9}$ \\
\hline H 3.c & $\mathrm{TDA}=\beta_{0}+\beta_{1} \mathrm{ACM}+\beta_{2} \mathrm{TA}+\beta_{3} \mathrm{DR}+\beta_{4} \mathrm{SG}+\beta_{5} \mathrm{CFO}+\varepsilon(1.2)^{10}$ & $\begin{array}{c}\beta_{1} \text { non- } \\
\text { significant }\end{array}$ \\
\hline \multicolumn{3}{|c|}{ CONDITIONAL CONSERVATISM } \\
\hline H 1.b & $\mathrm{NI}=\beta_{0}+\beta_{1} \mathrm{RN}+\beta_{2} \mathrm{R}+\beta_{3} \mathrm{RN} * \mathrm{R}+\beta_{4} \mathrm{ACM}+\beta_{5} \mathrm{ACM} * \mathrm{RN}+\beta_{6}$ & $\beta_{7}<0$ \\
\hline
\end{tabular}

\footnotetext{
${ }^{7}$ Similarly to Lara and Mora (2004), Giner and Rees (2001) the return is calculated as follows: $\mathrm{P}_{\mathrm{t}}-\mathrm{P}_{\mathrm{t}-1} / \mathrm{P}_{\mathrm{t}-1}$.

${ }^{8}$ The model (1.4) will be estimated for the continental and the Anglo-American models.

${ }^{9} \boldsymbol{\beta}_{1 C} \boldsymbol{e t} \boldsymbol{\beta}_{1 A}$ : Coefficients of the model estimation on respectively the continental and Anglo-American groups.

${ }^{10}$ The model (1.3) will be estimated distinctly for 2 periods (pre- and post-adoption of IFRS).
} 


\begin{tabular}{|l|l|l|}
\hline & \multicolumn{1}{|c|}{$\mathrm{ACM}^{*} \mathrm{R}+\beta_{7} \mathrm{ACM} * \mathrm{RN} * \mathrm{R}+\beta_{8} \mathrm{TA}+\beta_{9} \mathrm{DR}+\beta_{10} \mathrm{SG}+\varepsilon \quad(2.2)$} & \\
\hline $\mathrm{H}$ 2.b & $\begin{array}{l}\mathrm{NI}=\beta_{0}+\beta_{1} \mathrm{RN}+\beta_{2} \mathrm{R}+\beta_{3} \mathrm{RN} * \mathrm{R}+\beta_{4} \mathrm{IFRS}+\beta_{5} \mathrm{IFRS} * \mathrm{RN}+\beta_{6} \\
\mathrm{IFRS} * \mathrm{R}+\beta_{7} \mathrm{RN} * \mathrm{R} * \mathrm{IFRS}+\beta_{8} \mathrm{TA}+\beta_{9} \mathrm{DR}+\beta_{10} \mathrm{SG}+\varepsilon \quad(2.3)\end{array}$ & $\beta_{7}<0$ \\
\hline $\mathrm{H} 3 . \mathrm{b}$ & $\begin{array}{l}\mathrm{NI}=\beta_{0}+\beta_{1} \mathrm{RN}+\beta_{2} \mathrm{R}+\beta_{3} \mathrm{RN} * \mathrm{R}+\beta_{4} \mathrm{IFRS}+\beta_{5} \mathrm{IFRS} * \mathrm{RN}+\beta_{6} \\
\mathrm{IFRS} * \mathrm{R}+\beta_{7} \mathrm{RN} * \mathrm{R} * \mathrm{IFRS}+\beta_{8} \mathrm{TA}+\beta_{9} \mathrm{DR}+\beta_{10} \mathrm{SG}+\varepsilon \quad(2.3)^{11}\end{array}$ & $\beta_{7 C}>\beta_{7 A}{ }^{12}$ \\
\hline $\mathrm{H} 3 . \mathrm{c}$ & $\mathrm{NI}=\beta_{0}+\beta_{1} \mathrm{RN}+\beta_{2} \mathrm{R}+\beta_{3} \mathrm{RN} * \mathrm{R}+\beta_{4} \mathrm{ACM}+\beta_{5} \mathrm{ACM} * \mathrm{RN}+\beta_{6}$ & $\begin{array}{l}\beta_{7} \quad \text { non- } \\
\text { significant }\end{array}$ \\
\hline
\end{tabular}

TDA = Total discretionary accruals as estimated by modified Jones model; ACM $=$ Accounting model $(=1$ if Anglo-American and 0 otherwise $)$. The continental model comprises Germany, Austria, Belgium, Spain, France, Italy, Luxembourg, Portugal, Finland, Greece, Denmark and Sweden. The Anglo-American model includes Ireland, United Kingdom and Netherlands. IFRS $=$ indicator variable $(=1$ in the post IFRS adoption period and 0 otherwise) $; \mathbf{N I}=$ Net income before extraordinary items per share deflated by share price at the beginning of the period $; \mathbf{R}=$ Rate of return of the firm $; \mathbf{R N}=$ Dummy variable (= 1 in case of negative rate of return and 0 otherwise $) ; \mathbf{T A}=$ Natural logarithm of end-ofyear total assets $; \mathbf{D R}=$ Debt ratio $; \mathbf{S G}=$ sales growth $; \mathbf{C F O}$ cash flow from operational activities scaled by beginning total assets.

\subsubsection{Control Variables}

Similarly to previous studies, we have introduced control variables to take into account the factors that could influence the conservatism level in addition to independent variables. First,we have maintained the size $\boldsymbol{T A}$ measured by the natural logarithm of the company's total assets. Then, the variable $\boldsymbol{D R}$ (debt ratio) will be also introduced and it is measured by the total debts standardized by the total assets of the company,and also sales growth $\boldsymbol{S G}$. Finally, the variable $\boldsymbol{C F O}$ is equal to total operating cash flows standardized by total assets at the beginning of the period and will be introduced for the measurement models of unconditional conservatism.

\subsection{Analysis Of Descriptive Statistics}

Table 4 summarizes the descriptive statistics of the variables studied. It points out that the net income per share (scaled by share price at the beginning of the period) is on average equal to 0.015 ranging from -0.906 to 0.515 with a standard deviation of 0.168 . The median of this variable is 0,020 . The stock return varies from -0.844 to 2.446 with amean of 0.109 , a standard deviation of 0.560 and a median of 0,028 . The share price shows an average of 26.353 , with 2.69 as a minimum and 70 as a maximum and with a standard deviation of 26.368 and a median of 13,261 . The dispersion of this variable could be explained by the

\footnotetext{
${ }^{11}$ The model (2.3) will be estimated for both continental and Anglo-American groups.

${ }^{12} \boldsymbol{\beta}_{7 C} \boldsymbol{e t} \boldsymbol{\beta}_{7 A}$ : Coefficients of the model estimation on the continental and Anglo-American groups.

${ }^{13}$ The model (2.2) will be distinctly estimated for 2 periods (pre- and post-adoption of IFRS).
} 


\section{Macrothink \\ International Journal of Accounting and Financial Reporting \\ ISSN 2162-3082 2016, Vol. 6, No. 1}

difference in the pricing systems of the sampled countries.

Total accruals (standardized by total assets at the beginning of the period) shows amean of 0.013 , a median of- 0.012 and a standard deviation of 0.059 . This variable ranges between 0.114 and 0.082 . Discretionary accruals (relative to total assets) are on average equal to 0.026 , with a standard deviation of 0.054 . The median is at -0.014 , while the minimum and maximum for this variable are -0.122 and 0.038 respectively.

The descriptive statistics of the control variables are presented in table 4 for both models since they do not share the same number of observations. These variables have similar values. Thus, the mean of the variable TA is 5.815 for the conditional conservatism measurement model and 5.878 for the unconditional conservatism measurement model. The debt mean (standardized by total assets) is 0.579 for the first model and 0.582 for the second one. As for the sales growth,it is on average equal to 0.099 for conditional conservatism model and 0.070 for those belonging to the accruals measurement model. The values of other statistics (standard deviation, median, minimum and maximum) are also similar. The operating cash flow average (standardized by total assets in the beginning of the period) is 0.071 and its standard deviation is 0.069 . Its minimum is equal to -0.045 whereas its maximum rises to 0.181 with 0.073 for the median.

\subsection{Univariate Variable Analysis}

In order to analyze the variables' evolution before and after IFRS adoption under the accounting models. comparison tests are used only after verifying the normality of the variables. If the normality condition is verified. Student test will be the appropriate test for the average comparison of groups. otherwise Wilcoxon test is recommended. Normality of the variables was verified by the graphical method. representing their distributions as a histogram and a probability-probability diagram. Similarly. this condition was confirmed by skewness and kurtosis values which are far from zero confirming that the studied variables do not follow the normal distribution. Our analysis shows that the discretionary accruals variable follows a normal distribution; all other variables are not Gaussian. Table 5 shows comparison tests results conducted on variables from both models used in this study ${ }^{14}$.

\subsubsection{Comparison Before And After IFRS Adoption}

From table 5. we can conclude that the majority of variables present significant differences between the pre- and post- periods of the IFRS adoption. Thus. for the conditional conservatism sample. the variables R. PS and TA significantly increased after adopting IFRS.

\footnotetext{
${ }^{14}$ For better reliability, «Student » and «Wilcoxon » tests are conducted for all variables. The results of both tests give consistent results.
} 
Table 4: Descriptive Statistics related to sample firms

\begin{tabular}{|c|c|c|c|c|c|}
\hline Variable & Mean & STD & Median & Minimum & Maximum \\
\hline & \multicolumn{5}{|c|}{ VARIABLES OF BASU MODEL } \\
\hline $\mathrm{NI}$ & 0.015 & 0.168 & 0.020 & -0.906 & 0.515 \\
\hline $\mathrm{R}$ & 0.109 & 0.560 & 0.028 & -0.844 & 2.446 \\
\hline PS & 26.353 & 26.368 & 13.261 & 2.69 & 70 \\
\hline TA & 5.815 & 2.115 & 5.576 & 1.678 & 11.198 \\
\hline DR & 0.579 & 0.212 & 0.596 & 0.082 & 1.259 \\
\hline \multirow[t]{2}{*}{ SG } & 0.099 & 0.379 & 0.055 & -0.833 & 2.358 \\
\hline & \multicolumn{5}{|c|}{ VARIABLES OF ACCRUALS MODEL } \\
\hline TAC & -0.013 & 0.059 & -0.012 & -0.114 & 0.082 \\
\hline$\triangle \mathrm{REV}$ & 0.060 & 0.155 & 0.040 & -0.183 & 0.346 \\
\hline$\triangle \mathrm{REC}$ & 0.013 & 0.050 & 0.006 & -0.062 & 0.109 \\
\hline PPE & 0.498 & 0.387 & 0.409 & 0.042 & 1.176 \\
\hline $\mathrm{TA}$ & 5.878 & 1.812 & 5.697 & 3.326 & 8.967 \\
\hline TDA & -0.026 & 0.054 & -0.014 & -0.122 & 0.038 \\
\hline DR & 0.582 & 0.170 & 0.602 & 0.292 & 0.827 \\
\hline $\mathrm{SG}$ & 0.070 & 0.171 & 0.054 & -0.190 & 0.387 \\
\hline $\mathrm{CFO}$ & 0.071 & 0.069 & 0.073 & -0.045 & 0.181 \\
\hline
\end{tabular}

$\mathrm{NI}=$ Net income before extraordinary items per share deflated by share price at the beginning of the period; $\mathrm{R}=$ Rate of return of the firm; PS Share price 3 months after the end of the year. $;$ TAC $=$ Total accruals scaled by lagged Total assets; TDA $=$ Total discretionary accruals as estimated by modified Jones model; $\triangle \mathrm{REV}$ Change in revenues scaled by beginning total assets; $\triangle \mathrm{REC}=$ Change in receivables scaled by beginning total assets; $\mathrm{PPE}=$ Gross property plant and equipment scaled by beginning total assets; TA = Natural logarithm of end-of-year total assets; $\mathrm{DR}=$ Debt ratio; $\mathrm{SG}=$ sales growth; $\mathrm{CFO}$ cash flow from operational activities scaled by beginning total assets.

The NI (DR) decreased (increased) in the post IFRS adoption but the variation is not statistically significant. while SG decreased in a statistically significant way. Total accruals in the post-IFRS adoption period are more significant than those of the pre-adoption period of these standards. The same result is observed for discretionary accruals and the difference is statistically significant. Thus. we can conclude that there is a decrease in the unconditional conservatism level due to the adoption of IFRS. This result is in harmony with our expectations. For control variables. a statistically significant increase is observed for the variables TA and CFO but this is not the case for theDR and SG variables that decreased in a 
statistically significant way during the IFRS application period.

\subsubsection{Comparison By Accounting Model}

Table 6 summarizes the results of the variables analysis under each of the accounting models. It is clear from this table that there are significant differences between both models. For example. when we consider the unconditional conservatism sample. we find that discretionary accruals are less significant in countries operating under the Anglo-American model and the difference is statistically significant. This result is not consistent with our expectations. we need to conduct the multivariate analysis to conclude.

Table 5: Variables Comparison before and after the IFRS adoption

\begin{tabular}{|c|c|c|c|c|c|c|c|c|}
\hline & \multicolumn{3}{|c|}{ Before IFRS } & \multicolumn{3}{|c|}{ After IFRS } & \multirow[t]{2}{*}{ Z Wilcoxon } & \multirow[t]{2}{*}{ t Student } \\
\hline & Mean & STD & Median & Mean & STD & Median & & \\
\hline \multicolumn{9}{|c|}{ VARIABLES OF BASU MODEL } \\
\hline $\mathrm{NI}$ & 0.017 & 0.164 & 0.024 & 0.013 & 0.174 & 0.018 & 2.655 & 0.991 \\
\hline $\mathrm{R}$ & 0.066 & 0.572 & -0.003 & 0.159 & 0.542 & 0.059 & $10.085 * * *$ & $8.445^{* * *}$ \\
\hline PS & 24.638 & 25.518 & 17.795 & 28.423 & 27.218 & 15.88 & $4.987 * * *$ & $7.370 * * *$ \\
\hline $\mathrm{TA}$ & 5.642 & 2.087 & 5.413 & 6.025 & 2.130 & 5.814 & $9.457 * * *$ & $9.307 * * *$ \\
\hline DR & 0.577 & 0.215 & 0.595 & 0.582 & 0.208 & 0.596 & 1.238 & 0.273 \\
\hline SG & 0.125 & 0.418 & 0.056 & 0.068 & 0.326 & 0.053 & $4.230 * * *$ & $7.636 * * *$ \\
\hline \multicolumn{9}{|c|}{ VARIABLES OF ACCRUALS MODEL } \\
\hline TAC & -0.015 & 0.060 & -0.015 & -0.011 & 0.057 & -0.010 & $3.368 * * *$ & $3.040 * * *$ \\
\hline$\triangle \mathrm{REV}$ & 0.065 & 0.159 & 0.041 & 0.054 & 0.149 & 0.039 & $2.402 * *$ & $3.423 * * *$ \\
\hline$\triangle \mathrm{REC}$ & 0.014 & 0.052 & 0.006 & 0.012 & 0.047 & 0.006 & 0.770 & 1.964 \\
\hline PPE & 0.519 & 0.386 & 0.445 & 0.473 & 0.387 & 0.365 & $6.387 * * *$ & $5.673 * * *$ \\
\hline TA & 5.726 & 1.799 & 5.520 & 6.062 & 1.810 & 5.952 & $9.255 * * *$ & $9.204 * * *$ \\
\hline TDA & -0.029 & 0.054 & -0.018 & -0.023 & 0.054 & -0.007 & $5.639 * * *$ & $5.434 * * *$ \\
\hline DR & 0.584 & 0.173 & 0.607 & 0.578 & 0.166 & 0.596 & $2.437 * *$ & $1.850 * *$ \\
\hline $\mathrm{SG}$ & 0.077 & 0.176 & 0.053 & 0.063 & 0.165 & 0.056 & $2.341 * *$ & $3.863 * * *$ \\
\hline $\mathrm{CFO}$ & 0.068 & 0.0708 & 0.072 & 0.074 & 0.0672 & 0.075 & $3.639 * * *$ & $3.996 * * *$ \\
\hline
\end{tabular}

*** Significant at 1 percent; ** Significant at 5 percent. indicating that the means (medians) are significantly different between the two periods (before and after IFRS adoption) using ttest (Wilcoxon rank sum test) The period before IFRS. begins from 2000 and ends in 2004. while the period after IFRS is from 2006 to 2007 and from 2009 to 2010 . NI = Net income before extraordinary items per share deflated by share price at the beginning of the period ; $\mathrm{R}$ $=$ Rate of return of the firm ; PS Share price 3 months after the end of the year. ; TAC $=$ Total 


\section{NI Macrothink}

International Journal of Accounting and Financial Reporting ISSN 2162-3082 2016, Vol. 6, No. 1

accruals scaled by lagged Total assets; TDA = Total discretionary accruals as estimated by modified Jones model; $\triangle \mathrm{REV}$ Change in revenues scaled by beginning total assets; $\triangle \mathrm{REC}=$ Change in receivables scaled by beginning total assets; PPE $=$ Gross property plant and equipment scaled by beginning total assets; TA = Natural logarithm of end-of-year total assets; $\mathrm{DR}=$ Debt ratio; $\mathrm{SG}=$ sales growth; $\mathrm{CFO}$ cash flow from operational activities scaled by beginning total assets.

Table 6: Variables comparison by accounting model

\begin{tabular}{|c|c|c|c|c|c|c|c|c|}
\hline & \multicolumn{3}{|c|}{ Continental model } & \multicolumn{3}{|c|}{ Anglo-American model } & \multirow[t]{2}{*}{ Z Wilcoxon } & \multirow[t]{2}{*}{ t Student } \\
\hline & Mean & STD & Median & Mean & STD & Median & & \\
\hline \multicolumn{9}{|c|}{ VARIABLES OF BASU MODEL } \\
\hline $\mathrm{NI}$ & 0.016 & 0.181 & 0.032 & 0.013 & 0.103 & 0.001 & 0.418 & 0.491 \\
\hline $\mathrm{R}$ & 0.091 & 0.555 & 0.007 & 0.181 & 0.575 & 0.104 & $6.536 * * *$ & $7.814 * * *$ \\
\hline PS & 21.429 & 23.548 & 9.70 & 46.869 & 27.569 & 70.00 & $36.393 * * *$ & $42.429 * * *$ \\
\hline TA & 5.772 & 2.129 & 5.472 & 5.991 & 2.047 & 6.025 & $6.138 * * *$ & $4.222 * * *$ \\
\hline DR & 0.585 & 0.208 & 0.601 & 0.554 & 0.225 & 0.567 & $6.050 * * *$ & $5.836 * * *$ \\
\hline SG & 0.099 & 0.385 & 0.055 & 0.097 & 0.354 & 0.053 & 0.091 & 0.243 \\
\hline \multicolumn{9}{|c|}{ VARIABLES OF ACCRUALS MODEL } \\
\hline $\mathrm{TAC}$ & -0.014 & 0.059 & -0.014 & -0.009 & 0.058 & -0.004 & $4.379 * * *$ & $3.698 * * *$ \\
\hline$\triangle \mathrm{REV}$ & 0.059 & 0.153 & 0.039 & 0.065 & 0.162 & 0.042 & 1.012 & 1.466 \\
\hline$\triangle \mathrm{REC}$ & 0.013 & 0.050 & 0.006 & 0.012 & 0.047 & 0.005 & 0.508 & 0.897 \\
\hline PPE & 0.487 & 0.392 & 0.389 & 0.541 & 0.363 & 0.462 & $7.672 * * *$ & $5.424 * * *$ \\
\hline TA & 5.876 & 1.833 & 5.631 & 5.886 & 1.726 & 5.944 & 0.974 & 0.221 \\
\hline TDA & -0.025 & 0.055 & -0.011 & -0.032 & 0.051 & -0.021 & $7.248 * * *$ & $5.274 * * *$ \\
\hline DR & 0.589 & 0.168 & 0.610 & 0.551 & 0.175 & 0.558 & $8.686^{* * * *}$ & $8.953 * * *$ \\
\hline $\mathrm{SG}$ & 0.071 & 0.171 & 0.054 & 0.070 & 0.173 & 0.054 & 0.004 & 0.116 \\
\hline $\mathrm{CFO}$ & 0.067 & 0.068 & 0.070 & 0.084 & 0.069 & 0.087 & $9.507 * * *$ & $9.456 * * *$ \\
\hline
\end{tabular}

*** Significant at 1 percent; ** Significant at 5 percent. The continental model comprises Germany. Austria. Belgium. Spain. France. Italy. Luxembourg. Portugal. Finland. Greece. Denmark and Sweden. The Anglo-American model includes Ireland. United Kingdom and Netherlands. NI $=$ Net income before extraordinary items per share deflated by share price at the beginning of the period; $\mathrm{R}=$ Rate of return of the firm ; PS Share price 3 months after the end of the year.; TAC $=$ Total accruals scaled by lagged Total assets $;$ TDA $=$ Total discretionary accruals as estimated by modified Jones model; $\triangle \mathrm{REV}$ Change in revenues scaled by beginning total assets ; $\triangle \mathrm{REC}=$ Change in receivables scaled by beginning total assets $; \mathrm{PPE}=$ Gross property plant and equipment scaled by beginning total assets $; \mathrm{TA}=$ 


\section{Mll Macrothink}

International Journal of Accounting and Financial Reporting

ISSN 2162-3082

2016, Vol. 6, No. 1

Natural logarithm of end-of-year total assets; DR = Debt ratio; SG = sales growth ; CFO cash flow from operational activities scaled by beginning total assets.

\section{Results of the empirical analysis}

This analysis is preceded by a preliminary step of choosing the appropriate estimation method and also checking the multicolinearity between explanatory variables. The multicolinearity analysis between explanatory variables is achieved by analyzing the correlation matrix. Furthermore a VIF (Variance Inflation Factor) test was performed for greater accuracy about this issue. This analysis has been conducted on the different models of our study and reveals mostly the absence of any multicolinearity problems. In contrast, at the level of model (2.3), VIF value is significant for the IFRS $\boldsymbol{x}$ RN variable (VIF $=6.63>5$ ). Hence, the multicolinearity problem is present and drives us to delete this variable from our model.

\subsection{Hypothesis H 1 Test}

We have estimated the modified Jones model each year for each two-digit SIC industry since that number of observations is sufficient for such a procedure ${ }^{15}$. Due to the lack of observations, the Public administration sector (SIC code 90-99) was excluded from the analysis. Then discretionary accruals were regressed following the models presented in table3. We used Basu's (1997) measure for the conditional conservatism. In order to compare the accounting conservatism level of companies from countries operating under the continental model with those operating under the Anglo-American one. the ACM variable (which is equal to 1 for the Anglo-American model and 0 for the continental one) is introduced in Basu's (1997) model. Thus the model (2.2) is obtained as presented in table 3.

Panel A from table 7 summarizes results of the model (1.2) estimation and panel B recapitulates those of model (2.2). Concerning the unconditional conservatism, panel A denotes a strong relation between introduced variables of the model (1.2) and discretionary accruals level. For the verification of the first assumption, $\mathrm{H}$ 1.a. we will only need the $\boldsymbol{A C M}$ variable. Similarly to our expectations, this variable has a positive sign with a statistically significant coefficient. Thus companies in countries operating under the Anglo-American model use the discretionary accruals more than those belonging to countries operating under continental model. This result is consistent with our expectations and we can conclude that the hypothesis $\mathrm{H}$ 1.a is validated.

Concerning conditional conservatism we first notice that the coefficient $\boldsymbol{\beta}_{\mathbf{3}}$ is positive and significant indicating the existence of conservative accounting practices in companies that belong to countries operating under the continental model. The comparison between $\boldsymbol{\beta}_{3}$ and $\boldsymbol{\beta}_{2}$ shows that the accounting result is much more affected by bad news than good news. This observation supports the hypothesis of the presence of accounting conservatism in companies from the sampled countries operating under the continental model.

Regarding the conditional conservatism, the difference between the Anglo-American and the

\footnotetext{
${ }^{15}$ Lobo G. and J. Zhou (2006) specify that this procedure needs 6 observations at a minimum by sector (two-digit code SIC industry is used for this purpose).
} 
continental models is reflected in the variable $\boldsymbol{A C M} * \boldsymbol{R} \boldsymbol{N} * \boldsymbol{R}$. Results from Table 7 (Panel B) show that companies belonging to countries operating under the Anglo-American model have a lower conditional conservatism level than those belonging to countries operating under the continental model. In fact the coefficient $\beta_{7}$ is negative and significant (at the level of 1 percent). This result validates hypothesis $\mathrm{H}$ 1.b stating that the conditional conservatism level is higher in countries operating under the continental model.

Table 7: Analysis of the conservatism level in the sampled companies

\begin{tabular}{|c|c|c|c|}
\hline \multicolumn{2}{|c|}{ Panel A (Model 1.2):TDA $A_{i t}=\beta_{0}+\beta_{1} A C M+\beta_{2} T A_{i t}+\beta_{3} D R_{i t}+\beta_{4} S G_{i t}+\beta_{5} C F O_{i t}+\varepsilon_{i t}{ }^{(\mathrm{a})}$} \\
\hline Variable & & Coefficient & $\mathrm{Z}$ \\
\hline ACM & $\beta_{1}$ & 0.0077 & $5.80^{* * *}$ \\
\hline TA & $\beta_{2}$ & -0.0028 & $-8.64^{* * *}$ \\
\hline DR & $\beta_{3}$ & -0.0620 & $-17.75^{* * *}$ \\
\hline SG & $\beta_{4}$ & -0.0583 & $-16.36^{* * *}$ \\
\hline CFO & $\beta_{5}$ & -0.4003 & $-45.47^{* * *}$ \\
\hline Constant & $\beta_{0}$ & 0.0450 & $17.36^{* * *}$ \\
\hline Observations & 8581 & Wald Khi ${ }^{*}$ & $3308.97^{* * * *}$ \\
\hline
\end{tabular}

Panel B (Model 2.2) : NI $I_{i t}=\beta_{0}+\beta_{1} R N_{i t}+\beta_{2} R_{i t}+\beta_{3} R N_{i t} * R_{i t} \beta_{4} A C M_{i t}+\beta_{5} A C M_{i t} * R_{i t}+\beta_{6} A C M_{i t}$ $* R N_{i t} * R_{i t}+\beta_{7} T A_{i t}+\beta_{8} D R_{i t}+\beta_{9} S G_{i t}+\varepsilon_{i t}{ }^{(b)}$

\begin{tabular}{|c|c|c|c|}
\hline Variable & & Coefficient & $\mathrm{Z}$ \\
\hline $\mathrm{DR}$ & $\beta_{1}$ & -0.0004 & -0.77 \\
\hline $\mathrm{R}$ & $\beta_{2}$ & -0.0015 & $-3.10^{* * *}$ \\
\hline $\mathrm{RN} * \mathrm{R}$ & $\beta_{3}$ & 0.0272 & $19.65^{* * *}$ \\
\hline $\mathrm{ACM}$ & $\beta_{4}$ & -0.0150 & $-18.69 * * *$ \\
\hline $\mathrm{ACM} * \mathrm{R}$ & $\beta_{5}$ & 0.0003 & 0.26 \\
\hline
\end{tabular}




\begin{tabular}{|c|c|c|c|}
\hline $\mathrm{ACM} * \mathrm{RN}$ & $\beta_{6}$ & 0.0017 & 1.24 \\
\hline $\mathrm{ACM} * \mathrm{RN} * \mathrm{R}$ & $\beta_{7}$ & -0.0193 & $-5.05^{* * *}$ \\
\hline $\mathrm{TA}$ & $\beta_{8}$ & 0.0007 & $8.60 * * *$ \\
\hline $\mathrm{DR}$ & $\beta_{9}$ & -0.0005 & 6.67 \\
\hline $\mathrm{SG}$ & $\beta_{10}$ & 0.0031 & $37.44 * * *$ \\
\hline Constant & $\beta_{0}$ & 0.0274 & $1736.66^{* * *}$ \\
\hline Observations & 9623 & Wald $\mathrm{Khi}^{2}$ & \\
\hline
\end{tabular}

Significant at: $* * * 1$ percent $* * 5$ percent $* 10$ percent.

(a) Panel A estimates the model (1.2) and measures the impact of the accounting model on unconditional conservatism.

(b) Panel B estimates the model (2.2) and measures the impact of the accounting model on conditional conservatism.

TDA: Total discretionary accruals as estimated by modified Jones model ACM: Dichotomous Variable equal to 1 for a company operating under the Anglo-American model and 0 for continental model.NI: Net income before extraordinary items per share deflated by share price at the beginning of the period; R: the stock return. RN: Dichotomous variable equal to 1 in case of negative return and 0 otherwise. TA: Natural total assets Logarithm. DR: Total debt normalized by the total assets of the firm. SG: Sales growth of the firm. CFO: Operating Cash flows scaled by total assets in the beginning of the period.

\subsection{Hypothesis H 2 Test}

Analyzing the impact of the International Standards adoption on the unconditional conservatism level will be through the model (1.3) estimation and the model (2.3) concerning conditional conservatism. The results of this analysis are presented in table8. Panel A allows for comparing discretionary accruals before and after the adoption of International Standards. It shows that discretionary accruals increase in the post-period of the IFRS adoption. Indeed. the coefficient of the IFRS variable is positive and significant (1percent). Thus similarly to our expectations and to the results of the univariate analysis, the unconditional conservatism level has decreased because of the IFRS application. Consequently hypothesis H 2.a is validated.

In order to study the impact of IFRS adoption on the conditional conservatism level, we principally observe the coefficient of the variable $I F R S * R \boldsymbol{R} * \boldsymbol{R}$ from Panel B. Indeed, the interaction $I F R S * \boldsymbol{R N} * \boldsymbol{R}$ allows for judging the impact of IFRS on the recognition of bad 


\section{Ml Macrothink}

International Journal of Accounting and Financial Reporting

ISSN 2162-3082

2016, Vol. 6, No. 1

news over good news. From table 8 (Panel B), we notice that the accounting practices of the firms in the studied sample are conservative. In fact the coefficient $\beta_{3}$ is positive and significant (at 1 percent). Similarly to what we previously have estimated, the coefficient $\beta_{6}$ is negative and significant indicating that the recognition of bad news over good news decreases in the post-period of the IFRS adoption. The variation of the current recognition of bad news versus good through the IFRS adoption is measured as follows $\left(\beta_{5}+\beta_{6}\right) /\left(\beta_{2}+\beta_{3}\right)^{16}$. Thus IFRS adoption in European Union countries leads to a decrease of 34.48percent in the recognition of bad news over good ones. The hypothesis $\mathrm{H} 2 . \mathrm{b}$ is then validated.

\subsection{Hypothesis H 3 Test}

\subsubsection{Reduction Test Of The Conservatism Level}

Table 9 summarizes the estimation results of the models (1.3) and (2.3) for both AngloAmerican and continental groups. Thus it allows for comparing IFRS impact on the conservatism level following the accounting model of each country. With regard to unconditional conservatism table 9 (Panel A) shows that companies of the two sub-groups use more discretionary accruals in the post-IFRS adoption period. Besides the coefficient of the IFRS variable is positive and significant (at 1 percent) for both sub-samples. Thus contrary to what we expected. From table 9 we observe no difference between both of the accounting models studied. The decrease of unconditional conservatism after adopting IFRS is similar for the continental model and the Anglo-American one. Thus the hypothesis H3.a is not validated. Hence the reduction of the unconditional conservatism level may be affected by factors other than IFRS adoption and which are not introduced in this study.

Panel B summarizes the results concerning the impact of International Standards on the conditional conservatism level under the accounting model. First. it seems that conservative accounting exists for companies belonging to countries operating under the continental model but not for those countries operating under the Anglo-American one. Indeed. the coefficient $\beta_{3}$ related to the variable $\mathrm{RN} * \mathrm{R}$ is positive and significant (at 1 percent) for the first group and not for the latter. Table 9 shows that companies of countries operating under the continental model face a decrease in the conditional conservatism level in the post-IFRS adoption period. Thus the coefficient $\beta_{6}$ is negative and significant (at 5 percent) indicating that bad news is reflected in earnings more rapidly than good news after the application of IFRS.

\footnotetext{
${ }^{16}\left(\boldsymbol{\beta}_{2}+\boldsymbol{\beta}_{3}\right)$ measures the conditional conservatism degree in the pre-periodof IFRS adoption . $\left(\boldsymbol{\beta}_{5}+\boldsymbol{\beta}_{6}\right)$ measures the conditional conservatism degree in the post-periodof IFRS adoption.
} 
Table 8: Analysis of IFRS impact on the conservatism level

\begin{tabular}{|l|l|l|l|}
\hline \multicolumn{2}{|l|}{ Panel A: TDA $A_{i t}=\beta_{0}+\beta_{1} I F R S_{i t}+\beta_{2} T A_{i t}+\beta_{3} D R_{i t}+\beta_{4} S G_{i t}+\beta_{5} C F O_{i t}+\varepsilon_{i t} \quad(1.3)^{(\mathrm{a})}$} \\
\hline Variable & & Coefficient & $\mathrm{Z}$ \\
\hline IFRS & $\beta_{1}$ & 0.0032 & $6.75^{* * *}$ \\
\hline TA & $\beta_{2}$ & -0.0034 & $-11.18^{* * *}$ \\
\hline DR & $\beta_{3}$ & -0.0186 & $-8.46^{* * *}$ \\
\hline SG & $\beta_{4}$ & -0.0342 & $-35.44^{* * *}$ \\
\hline CFO & $\beta_{4}$ & -0.0357 & $-11.98^{* * *}$ \\
\hline Constant & $\beta_{0}$ & 0.0191 & $9.13^{* * *}$ \\
\hline Observations & 8581 & Wald Khi ${ }^{2}$ & $1835.04 * * *$ \\
\hline
\end{tabular}

Panel B: $N I_{i t}=\beta_{0}+\beta_{1} R N_{i t}+\beta_{2} R_{i t}+\beta_{3} R N_{i t} * R_{i t+} \beta_{4} I F R S_{i t}+\beta_{5} I F R S_{i t} * R_{i t}+\beta_{6} I F R S_{i t} * R N_{i t} *$ $R_{i t}+\beta_{7} T A_{i t}+\beta_{8} D R_{i t}+\beta_{9} S G_{i t}+\varepsilon_{i t} \quad(2.3)^{(\mathrm{b})}$

\begin{tabular}{|l|l|l|l|}
\hline Variable & & Coefficient & $\mathrm{Z}$ \\
\hline $\mathrm{RN}$ & $\beta_{1}$ & 0.0143 & $2.60 * * *$ \\
\hline $\mathrm{R}$ & $\beta_{2}$ & 0.0088 & 1.38 \\
\hline $\mathrm{RN} * \mathrm{R}$ & $\beta_{3}$ & 0.1011 & $6.14 * * *$ \\
\hline $\mathrm{IFRS}$ & $\beta_{4}$ & -0.0229 & $-4.23 * * *$ \\
\hline $\mathrm{IFRS} * \mathrm{R}$ & $\beta_{5}$ & 0.0131 & 1.40 \\
\hline $\mathrm{IFRS} * \mathrm{RN} * \mathrm{R}$ & $\beta_{6}$ & -0.0510 & $-1.97 * *$ \\
\hline $\mathrm{TA}$ & $\beta_{7}$ & 0.0090 & $10.28 * * *$ \\
\hline $\mathrm{RN}$ & $\beta_{8}$ & -0.0402 & $-4.39 * * *$ \\
\hline
\end{tabular}




\begin{tabular}{|l|l|l|l|}
\hline SG & $\beta_{9}$ & 0.0505 & $8.91^{* * *}$ \\
\hline Constant & $\beta_{0}$ & -0.0035 & -0.43 \\
\hline Observations & 9623 & Wald $\mathrm{Khi}^{2}$ & $335.53 * * *$ \\
\hline
\end{tabular}

Significant at $: * * * 1$ percent; $* * 5$ percent $; * 10$ percent.

(a) Panel A estimates the model (1.3) and measures the impact of the IFRS adoption on unconditional conservatism.

(b) Panel B estimates the model (2.3) and measures the impact of IFRS adoption on conditional conservatism.

TDA: Total discretionary accruals as estimated by modified Jones model. IFRS: Dichotomous Variable equal to 1 in the IFRS post adoption period and 0 elsewhere. NI: Net income before extraordinary items per share deflated by share price at the beginning of the period; R: the stock return. RN: Dichotomous variable equal to 1 in case of negative return and 0 otherwise. TA: Natural total assets Logarithm. DR: Total debt normalized by the total assets of the firm. SG: Sales growth of the firm. CFO: Operating Cash flows scaled by total assets in the beginning of the period.

Table 9: Analysis of the IFRS impact on conservatism level following the accounting model

\begin{tabular}{|c|c|c|c|c|c|}
\hline \multirow[b]{2}{*}{ Variable } & & \multicolumn{2}{|c|}{ Continental model } & \multicolumn{2}{|c|}{ Anglo-American model } \\
\hline & & Coefficient & $\mathrm{Z}$ & Coefficient & $\mathrm{Z}$ \\
\hline IFRS & $\beta_{1}$ & 0.0018 & $3.55 * * *$ & 0.0101 & $7.84 * * *$ \\
\hline TA & $\beta_{2}$ & -0.003 & $-9.02 * * *$ & -0.0045 & $-6.13 * * *$ \\
\hline DR & $\beta_{3}$ & -0.0182 & $-7.64 * * *$ & -0.0150 & $-2.72 * * *$ \\
\hline SG & $\beta_{4}$ & -0.0314 & $-30.79 * * *$ & -0.0459 & $-17.55 * * *$ \\
\hline $\mathrm{CFO}$ & $\beta_{5}$ & -0.0301 & $-9.63 * * *$ & -0.0588 & $-7.01 * * *$ \\
\hline Constant & $\beta_{6}$ & 0.0195 & $8.47 * * *$ & 0.0140 & $2.84 * * *$ \\
\hline
\end{tabular}




\begin{tabular}{|c|c|c|c|c|c|}
\hline Observations & & \multicolumn{2}{|l|}{6756} & \multicolumn{2}{|l|}{1825} \\
\hline Wald $\mathrm{Khi}^{2}$ & & \multicolumn{2}{|l|}{$1323.16^{* * *}$} & \multicolumn{2}{|l|}{$528.34 * * *$} \\
\hline \multicolumn{6}{|c|}{$\begin{array}{l}\text { Panel B: }: I_{i t}=\beta_{0}+\beta_{1} R N_{i t}+\beta_{2} R_{i t}+\beta_{3} R N_{i t} * R_{i t}+\beta_{4} I F R S_{i t}+\beta_{5} I F R S_{i t} * R_{i t}+ \\
\beta_{6} I F R S_{i t} * R N_{i t} * R_{i t}+\varepsilon_{i t}(2.3)^{(\mathrm{b})}\end{array}$} \\
\hline & & \multicolumn{2}{|c|}{ Continental model } & \multicolumn{2}{|c|}{ Anglo-American model } \\
\hline Variable & & Coefficient & $\mathrm{Z}$ & Coefficient & Z \\
\hline RN & $\beta_{1}$ & 0.0184 & $2.46 * *$ & 0.0001 & 0.08 \\
\hline $\mathrm{R}$ & $\beta_{2}$ & 0.0138 & 1.51 & -0.0008 & -0.43 \\
\hline $\mathrm{RN}^{*} \mathrm{R}$ & $\beta_{3}$ & 0.1269 & $5.68 * * *$ & 0.0092 & 1.50 \\
\hline IFRS & $\beta_{4}$ & -0.0288 & $-3.85 * * *$ & -0.0008 & -0.52 \\
\hline IFRS $* \mathrm{R}$ & $\beta_{5}$ & 0.0190 & 1.44 & -0.0008 & -0.29 \\
\hline IFRS $* \mathrm{RN} * \mathrm{R}$ & $\beta_{6}$ & -0.0665 & $-1.88 * *$ & -0.0012 & -0.14 \\
\hline TA & $\beta_{7}$ & 0.0105 & $9.02 * * *$ & 0.0020 & $5.95 * * *$ \\
\hline $\mathrm{RN}$ & $\beta_{8}$ & -0.0564 & $-4.38 * * *$ & -0.0082 & $-3.030 * * *$ \\
\hline SG & $\beta_{9}$ & 0.0667 & $8.79 * * *$ & 0.0010 & 0.57 \\
\hline Constant & $\beta_{0}$ & 0.0009 & 0.08 & -0.0021 & -0.90 \\
\hline$\Delta \mathrm{CC}$ (percentage) & & \multicolumn{2}{|l|}{-33.759} & \multicolumn{2}{|l|}{-23.80} \\
\hline Observations & & \multicolumn{2}{|l|}{7654} & \multicolumn{2}{|l|}{1969} \\
\hline Wald $\mathrm{Khi}^{2}$ & & \multicolumn{2}{|l|}{$307.49 * * *$} & \multicolumn{2}{|l|}{$43.78 * * *$} \\
\hline
\end{tabular}

Significant at: $* * * 1$ percent; $* * 5$ percent; $* 10$ percent. The continental model comprises Germany. Austria. Belgium. Spain. France. Italy. Luxembourg. Portugal. Finland. Greece. Denmark and Sweden. The Anglo-American model includes Ireland. United Kingdom and Netherlands. 


\section{MInstitute Mati $^{\text {Macrothink }}$}

International Journal of Accounting and Financial Reporting

ISSN 2162-3082

(a) Panel A estimates the model (1.3) and measures the impact of the IFRS adoption on unconditional conservatism following the accounting model.

(b) Panel B estimates the model (2.3) and measures the impact of IFRS adoption on conditional conservatism following the accounting model.

TDA: Total discretionary accruals as estimated by modified Jones model. IFRS: Dichotomous Variable equal to 1 in the IFRS post adoption period and 0 elsewhere. NI: Net income before extraordinary items per share deflated by share price at the beginning of the period; R: the stock return. RN: Dichotomous variable equal to 1 in case of negative return and 0 otherwise. TA: Natural total assets Logarithm. DR: Total debt normalized by the total assets of the firm. SG: Sales growth of the firm. CFO: Operating Cash flows scaled by total assets in the beginning of the period. $\triangle \mathrm{CC}$ : conditional conservatism level variation.

For the Anglo-American sample. the coefficient $\beta_{6}$ is negative but statistically nonsignificant. Consequently. IFRS did not have a notable impact on the recognition of bad news over good. Besides. in order to compare the impact of IFRS on the recognition of bad news over good. the ratio $\left(\boldsymbol{\beta}_{5}+\boldsymbol{\beta}_{6}\right) /\left(\boldsymbol{\beta}_{2}+\boldsymbol{\beta}_{3}\right)$ was calculated for both sub-samples. For the continental group. a decrease of 33.759percent resulted in the conditional conservatism level after adopting IFRS. However. a decrease of only 23.80percentwas observed for the AngloAmerican group. The hypothesis H3.b. stating that the decrease in the conditional conservatism level is more important in countries operating under the continental model is thus validated.

\subsubsection{Test Of The Conservatism Gap Decrease Between Both Models}

Table 10 summarizes the results of the conservatism level analysis following the accounting model before and after IFRS adoption. Our objective is to verify that the conservatism difference between both models decreases after the implementation of IFRS. If so. we can conclude that these standards lead to the harmonization of the accounting practices and thus to reaching the objective of the IASB.

Panel A from table 10 presents the results concerning conditional conservatism. The model (2.2) was estimated by distinguishing the two periods. both before and after the IFRS adoption. Through comparing the coefficient of the variable $A C M * R N * R$ we will be able to verify the third hypothesis H3.c. From table 10 (Panel A). considering the pre-IFRS adoption period. this coefficient is negative and significant (1percent). This result allows us to conclude that before adopting IFRS. the conservatism level is higher in countries operating under the continental model than in those operating under the Anglo-American one. However in the post-IFRS adoption period, the $\boldsymbol{A C M} * \boldsymbol{R} \boldsymbol{N} * \boldsymbol{R}$ variable has a negative coefficient although this is statistically non-significant. This result allows us to conclude that the difference in the conservatism level between countries operating under both models diminished after IFRS adoption. Indeed. the ratio $\left(\boldsymbol{\beta}_{5}+\boldsymbol{\beta}_{7}\right) /\left(\boldsymbol{\beta}_{2}+\boldsymbol{\beta}_{3}\right)$ confirms our results. In fact, before IFRS adoption countries operating under the continental model were 84.22 percent more conservative than those operating under an Anglo-American model. This ratio is reduced to 46.69 percent after the adoption of IFRS. Thus IFRS promote the harmonization 
of accounting practices because of accounting conservatism. The hypothesis H 3.c is then validated for conditional conservatism.

In order to verify whether the unconditional conservatism gap decreases in the post-adoption period of IFRS, the model (1.3) is estimated separately for both adoption periods. The coefficient interpretation of the $\boldsymbol{A C M}$ variable allows concluding that there is no difference between the two models after adopting IFRS. Indeed. the coefficient of this variable is significant at the 1 percent level for the two periods (before and after the adoption of IFRS). Thus hypothesis H3.c is not validated for this conservatism measure. This result is not in line with our expectations but is consistent with the result obtained for the hypothesis H3a.

Table 10: Analysis of the conservatism gap following accounting model

\begin{tabular}{|c|c|c|c|c|c|}
\hline \multicolumn{6}{|c|}{$\begin{array}{l}\text { PANEL A: } N I_{i t}=\beta_{0}+\beta_{1} R N_{i t}+\beta_{2} R_{i t}+\beta_{3} R N_{i t} * R_{i t+} \beta_{4} A C M_{i t}+\beta_{5} A C M_{i t} * R_{i t}+\beta_{6} A C M_{i t} \\
* R N_{i t}+\beta_{7} A C M_{i t} * R N_{i t} * R_{i t}+\beta_{8} T A_{i t}+\beta_{9} D R_{i t}+\beta_{10} S G_{i t}+\varepsilon_{i t}\end{array}$} \\
\hline & & \multicolumn{2}{|c|}{ Before IFRS } & \multicolumn{2}{|l|}{ After IFRS } \\
\hline & & Coefficient & $\mathrm{Z}$ & Coefficient & $\mathrm{Z}$ \\
\hline RN & $\beta_{1}$ & 0.0002 & 0.30 & -0.0010 & -1.26 \\
\hline $\mathrm{R}$ & $\beta_{2}$ & -0.0018 & $-2.68 * *$ & -0.0012 & $-1.78 *$ \\
\hline $\mathrm{RN}^{*} \mathrm{R}$ & $\beta_{3}$ & 0.0297 & $17.18 * * *$ & 0.0224 & $9.32 * * *$ \\
\hline $\mathrm{ACM}$ & $\beta_{4}$ & -0.0161 & $-14.60 * * *$ & -0.0140 & $-11.98 * * *$ \\
\hline $\mathrm{ACM} * \mathrm{R}$ & $\beta_{5}$ & 0.0024 & 1.28 & -0.0018 & -0.93 \\
\hline $\mathrm{ACM} * \mathrm{RN}$ & $\beta_{6}$ & 0.0017 & 0.89 & 0.0024 & 1.13 \\
\hline $\mathrm{ACM} * \mathrm{RN} * \mathrm{R}$ & $\beta_{7}$ & -0.0259 & $-5.33 * * *$ & -0.0081 & -1.28 \\
\hline$T A$ & $\beta_{8}$ & 0.0004 & $3.64 * * *$ & 0.0010 & $8.50 * * *$ \\
\hline$R N$ & $\beta_{9}$ & 0.0013 & 1.17 & -0.0026 & $-2.13 * *$ \\
\hline$S G$ & $\beta_{10}$ & 0.0017 & $3.01 * * *$ & 0.0055 & $6.92 * * *$ \\
\hline Constant & $\beta_{0}$ & 0.0286 & $28.72 * * *$ & 0.0261 & $24.24 * * *$ \\
\hline
\end{tabular}




\begin{tabular}{|c|c|c|c|c|c|}
\hline$\Delta \mathrm{CC}$ (percentage) & & \multicolumn{2}{|l|}{-84.22} & \multicolumn{2}{|l|}{-46.69} \\
\hline Observations & & \multicolumn{2}{|l|}{5049} & \multicolumn{2}{|l|}{4574} \\
\hline Wald $\mathrm{Khi}^{2}$ & & \multicolumn{2}{|l|}{$1047.72 * * *$} & \multicolumn{2}{|l|}{$737.61 * * *$} \\
\hline \multicolumn{6}{|c|}{ PANEL B: $T D A_{i t}=\beta_{0}+\beta_{1} A C M_{i t}+\beta_{2} T A_{i t}+\beta_{3} D R_{i t}+\beta_{4} S G_{i t}+\beta_{5} C F O_{i t}+\varepsilon_{i t}(1.2)^{(\text {a) }}$} \\
\hline & & \multicolumn{2}{|c|}{ Before IFRS } & \multicolumn{2}{|l|}{ After IFRS } \\
\hline & & Coefficient & $\mathrm{Z}$ & Coefficient & $\mathrm{Z}$ \\
\hline $\mathrm{ACM}$ & $\beta_{1}$ & 0.0099 & $8.65 * * *$ & 0.0204 & $11.76 * * *$ \\
\hline TA & $\beta_{2}$ & -0.0059 & $-19.24 * * *$ & -0.0004 & -0.09 \\
\hline DR & $\beta_{3}$ & -0.0580 & $-21.73 * * *$ & -0.0789 & $-17.71 * * *$ \\
\hline SG & $\beta_{4}$ & -0.1210 & $-51.70 * * *$ & -0.0817 & $-15.73 * * *$ \\
\hline $\mathrm{CFO}$ & $\beta_{5}$ & -0.4372 & $-53.66 * * *$ & -0.5022 & $-44.22 * * *$ \\
\hline Constant & $\beta_{6}$ & 0.0588 & $33.68 * * *$ & -0.0461 & $13.41 * * *$ \\
\hline Observations & & \multicolumn{2}{|l|}{4530} & \multicolumn{2}{|l|}{4051} \\
\hline Wald $\mathrm{Khi}^{2}$ & & \multicolumn{2}{|l|}{$9402.34 * * *$} & \multicolumn{2}{|l|}{$2662.21 * * *$} \\
\hline
\end{tabular}

Significant at: $* * * 1$ percent; $* * 5$ percent $; * 10$ percent. The period before IFRS begins from 2000 and ends in 2004, while the period after IFRS is from 2006 to 2007 and from 2009 to 2010.

(a) Panel A estimates the model (2.2) and measures the difference between the two accounting models in terms of conditional conservatism before and after IFRS adoption.

(b) Panel B estimates the model (1.2) and measures the difference between the two accounting models in terms of unconditional conservatism before and after IFRS adoption.

TDA: Total discretionary accruals as estimated by modified Jones model. ACM: Dichotomous Variable equal to 1 for a company operating under the Anglo-American model and 0 for continental model; NI: Net income before extraordinary items per share deflated by 


\section{MInstitute ${ }^{m+1}$ Macrothink}

International Journal of Accounting and Financial Reporting ISSN 2162-3082

share price at the beginning of the period; R: the stock return. RN: Dichotomous variable equal to 1 in case of negative return and 0 otherwise. TA: Natural total assets Logarithm. DR: Total debt normalized by the total assets of the firm. SG: Sales growth of the firm. CFO: Operating Cash flows scaled by total assets in the beginning of the period. $\Delta \mathrm{CC}$ : conditional conservatism level variation.

We should also note that the difference between the two models does not definitely disappear. The unconditional conservatism level is always higher in countries operating under the continental model even after IFRS adoption. Consequently, IFRS contribute to the accounting practices harmonization even if differences are not totally eliminated. There are probably factors other than accounting standards that determine accounting practices in the European Union region.

\section{Conclusion and Future Research Avenues}

The objective of this research is to verify whether mandatory IFRS adoption by countries from the European Union leads to a decrease in the level of accounting conservatism. Then we aim to investigate whether there is narrowing of the conservatism gap between the two accounting models. The verification of this objective is based on a sample of 1216 companies for the model measuring conditional conservatism and 1126 for the one measuring unconditional conservatism. Both sub-samples are observed under two sub-periods. the preperiod of IFRS adoption which is from 2000 to 2004 and the post-adoption period of these standards from 2006 to 2007 and from 2009 to 2010. Conservatism is categorized under two forms: unconditional and then conditional conservatism. The first has been measured by discretionary accruals as has been done in previous studies (Anwer. Billings. Morton andHarris 2002; Lobo and Zhou 2006; Gassen et al. 2006; Anwer and Duellman 2007; He et al. 2008). The second has been measured by Basu's (1997) model.

\subsection{Analysis Of The IFRS Impact On Conservatism}

Globally. the results show a decrease of the conservatism level in the post adoption period. More specifically. the results of our study show that the analyzed companies use more discretionary accruals when applying IFRS. The recognition of bad news over good ones decreases when financial statements are prepared under IFRS. Similarly to what Paananen and Lin (2009) observed. this result proves that bad news recognition diminished after the mandatory adoption of the IFRS. In the same way.our study has shown an increase of discretionary accruals in the post IFRS adoption.which means a decrease in the unconditional conservatism level.

\subsection{Accounting And Conservative Models}

Further analysis taking into account the accounting model used showed that the decrease in the conditional conservatism level of the continental sample is more significant than the decrease observed in the Anglo-American group. This observation could be explained by IFRS similarities with the Anglo-American model. Thus the IFRS implementation would be more significant in countries operating under the continental model. The previous result is aligned with earlier research on the impact of IFRS adoption. In this context, Zeghal et al. 
(2012) showed that the conservatism decreased after the mandatory adoption of IFRS. They also found that the decrease in the conservatism level after IFRS adoption is more important for countries with local standards significantly different from International Standards. However the results of our study show that there is no significant difference in the decrease of the unconditional conservatism level for continental and Anglo-American models. Furthermore, we were able to notice a decrease in the conditional conservatism gap between the countries operating under the continental model and those operating under the AngloAmerican one. This important observation allows us to conclude that the IASB is realizing its objective through internationally harmonizing accounting practices. Nevertheless. the gap is not significantly reduced for the unconditional conservatism. This result would be explained by the existence of other factors affecting the accounting practice in the European Union.

The results of our study confirm those of previous researches such as Zeghal et al. (2012). Anwer et al. (2013) and André et al. (2015). However we obtain different results from Piot et al. (2010) and Zhuang et al. (2014). In fact the former found a decrease in conditional conservatism but an increase in unconditional conservatism. The latter stated that there is no change in accounting conservatism (they employed conditional conservatism) for non financial firms and that there is a significant decrease only for firms domiciled in weak legal enforcement countries. The differences in the results obtained can be explained by methodological differences and measures of conservatism.

Future researchers could conduct similar analyses in the context of other countries or groups of countries that have adopted IFRS. This could be especially relevant in the case of emergent countries and other European countries that are not covered by this study.

\section{References}

Ahmed, A., \& Duellman, S. (2007). Accounting conservatism and board of director characteristics: An empirical analysis. Journal Of Accounting And Economics, 43(2-3), 411437. http://dx.doi.org/10.1016/j.jacceco.2007.01.005

Ahmed, A., Billings, B., Morton, R., \& Stanford-Harris, M. (2002). The Role of Accounting Conservatism in Mitigating Bondholder-Shareholder Conflicts over Dividend Policy and in Reducing Debt Costs. The Accounting Review, 77(4), 867-890. http://dx.doi.org/10.2308/accr.2002.77.4.867

Ahmed, A., Neel, M., \& Wang, D. (2013). Does Mandatory Adoption of IFRS Improve Accounting Quality? Preliminary Evidence. Contemporary Accounting Research, 30(4), 1344-1372. http://dx.doi.org/10.1111/j.1911-3846.2012.01193.x

André, P., Filip, A., \& Paugam, L. (2015). The Effect of Mandatory IFRS Adoption on Conditional Conservatism in Europe. Journal Of Business Finance \& Accounting, 42(3-4), 482-514. http://dx.doi.org/10.1111/jbfa.12105

Ball, R. (2006). International Financial Reporting Standards (IFRS): pros and cons for investors. Accounting And Business Research, 36(sup1), 5-27. http://dx.doi.org/10.1080/00014788.2006.9730040 


\section{Al Macrothink}

International Journal of Accounting and Financial Reporting

ISSN 2162-3082 2016, Vol. 6, No. 1

Ball, R., \& Shivakumar, L. (2005). Earnings quality in UK private firms: comparative loss recognition timeliness. Journal of Accounting And Economics, 39(1), 83-128. http://dx.doi.org/10.1016/j.jacceco.2004.04.001

Ball, R., Kothari, S., \& Robin, A. (2000). The effect of international institutional factors on properties of accounting earnings. Journal Of Accounting And Economics, 29(1), 1-51. http://dx.doi.org/10.1016/s0165-4101(00)00012-4

Basu, S. (1997). The conservatism principle and the asymmetric timeliness of earnings1. Journal Of Accounting And Economics, 24(1), 3-37. http://dx.doi.org/10.1016/s01654101(97)00014-1

Beaver, W., \& Ryan, S. (2005). Conditional and Unconditional Conservatism:Concepts and Modeling. Rev Acc Stud, 10(2-3), 269-309. http://dx.doi.org/10.1007/s11142-005-1532-6

Borker, D. (2013). Is there a favorable cultural profile for IFRS?: An examination and extension of Gray's accounting value hypotheses. International Business \& Economics Research Journal, 12(2), 167-177.

Byungcherl, C. (2012). Analyst forecast, accounting conservatism and the related valuation implications. Accounting And Finance, 52, 311-341.

Cheng Agnes, C., \& Liu, C. (2007). The effect of accounting conservatism on value relevance of earnings from the perspective of investment in long-term operating assets. Working Paper, University of Houston.

D'Arcy, A. (2001). Accounting classification and the international harmonisation debate: an empirical investigation. Accounting, Organizations And Society, 26(4-5), 327-349. http://dx.doi.org/10.1016/s0361-3682(00)00036-2

Daske, H. (2006). Economic Benefits of Adopting IFRS or US-GAAP - Have the Expected Cost of Equity Capital Really Decreased?. J Bus Fin \& Acc, 33(3-4), 329-373. http://dx.doi.org/10.1111/j.1468-5957.2006.00611.x

Daske, H., \& Gebhardt, G. (2006). International financial reporting standards and experts' perceptions of disclosure quality. Abacus, 42(3-4), 461-498. http://dx.doi.org/10.1111/j.14676281.2006.00211.x

Dechow, P., Sloan, R., \& Sweeny, A. (1995). Detecting earnings management. Accounting Review, 70(2), 193-225.

Dumontier, P., \& Raffournier, B. (2005). L'application des IFRS ou l'importance croissante de la juste valeur en comptabilitÃ $\odot$. Banque \& March $\tilde{A} \odot, ~ 79,56-62$.

Ferreira, L., Garcia Lara, J., \& Gonçalves, T. (2007). Accounting conservatism in Portugal: similarities and differences facing Germany and the United Kingdom. Rev. Adm. Contemp., 11(spe2). http://dx.doi.org/10.1590/s1415-65552007000600009

Francis, J., LaFond, R., Olsson, P., \& Schipper, K. (2004). Costs of Equity and Earnings $\begin{array}{llll}\text { Attributes. The } & \text { Accounting } & \text { 79(4), } & \text { 967-1010. }\end{array}$ 
http://dx.doi.org/10.2308/accr.2004.79.4.967

Gassen J., Fülbier R. U., and Sellhorn T. (2006). International Differences in Conditional

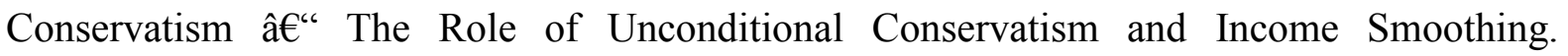
European Accounting Review, 15(4), 527-564. http://dx.doi.org/10.1080/09638180601102107

Giner, B., \& Rees, W. (2001). On the Asymmetric Recognition of Good and Bad News in France, Germany and the United Kingdom. J Bus Fin \& Acc, 28(9\&10), 1285-1331. http://dx.doi.org/10.1111/1468-5957.00416

Givoly, D., Hayn, C., \& Natarajan, A. (2007). Measuring Reporting Conservatism. The Accounting Review, 82(1), 65-106. http://dx.doi.org/10.2308/accr.2007.82.1.65

Grambovas, C., Giner, B., \& Christodoulou, D. (2006). Earnings conservatism: panel data evidence from the European Union and the United States. Abacus, 42(3-4), 354-378. http://dx.doi.org/10.1111/j.1467-6281.2006.00205.x

Gray, S. (1980). The Impact of International Accounting Differences from a SecurityAnalysis Perspective: Some European Evidence. Journal Of Accounting Research, 18(1), 64. http://dx.doi.org/10.2307/2490392

Gray, S. (1988). Towards a Theory of Cultural Influence on the Development of Accounting Systems Internationally. Abacus, 24(1), 1-15. http://dx.doi.org/10.1111/j.14676281.1988.tb00200.x

He, H., El-Masry, E., \& Wu, Y. (2008). Accounting conservatism of cross-listing firms in the pre- and post-Sarbanes Oxley periods. Advances In Accounting, 24(2), 237-242. http://dx.doi.org/10.1016/j.adiac.2008.08.004

Heidi, T. (2009). Twenty Questions on International Financial Reporting Standards. CPA Journal, 79(3), 32-37.

Hellman, N. (2008). Accounting Conservatism under IFRS. Accounting In Europe, 5(2), 71100. http://dx.doi.org/10.1080/17449480802510492

Hoogendoorn, M. (2006). International Accounting Regulation and IFRS Implementation in Europe and Beyond-Experiences with First-time Adoption in Europe. Accounting In Europe, 3(1), 23-26. http://dx.doi.org/10.1080/09638180600920087

Hung, M., \& Subramanyam, K. (2007). Financial statement effects of adopting international accounting standards: the case of Germany. Rev Acc Stud, 12(4), 623-657. http://dx.doi.org/10.1007/s11142-007-9049-9

Jermakowicz, E., \& Gornik-Tomaszewski, S. (2006). Implementing IFRS from the perspective of EU publicly traded companies. Journal Of International Accounting, Auditing And Taxation, 15(2), 170-196. http://dx.doi.org/10.1016/j.intaccaudtax.2006.08.003

Joos, P., \& Lang, M. (1994). The Effects of Accounting Diversity: Evidence from the European Union. Journal Of Accounting Research, 32, 141. http://dx.doi.org/10.2307/2491444 


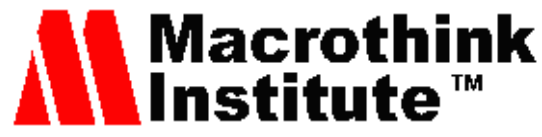

International Journal of Accounting and Financial Reporting ISSN 2162-3082

Kothari, S., Lys, T., Smith, C., \& Watts, R. (1988). Auditor liability and information disclosure. Journal Of Accounting, Auditing \& Finance, 3(4), 307-338.

Lang, M., Raedy, J., \& Yetman, M. (2003). How Representative Are Firms That Are CrossListed in the United States? An Analysis of Accounting Quality. J Accounting Res, 41(2), 363-386. http://dx.doi.org/10.1111/1475-679x.00108

Lara, J., \& Mora, A. (2004). Balance sheet versus earnings conservatism in Europe. European Accounting Review, 13(2), 261-292. http://dx.doi.org/10.1080/0963818042000203347

Larson, R., \& Street, D. (2004). Convergence with IFRS in an expanding Europe: progress and obstacles identified by large accounting firms' survey. Journal Of International Accounting, Auditing And Taxation, 89-119. http://dx.doi.org/10.1016/j.intaccaudtax.2004.09.002

Lewis, P., \& Salter, S. (2006). Europe and America-Together or Apart: An Empirical Test of Differences in Actual Reported Results. Advances In International Accounting, 19, 221-242. http://dx.doi.org/10.1016/s0897-3660(06)19009-1

Mensah, Y., Considine, J., \& Oakes, L. (1994). Adverse public policy implications of the accounting conservatism doctrine: The case of premium rate regulation in the HMO industry. Journal Of Accounting And Public Policy, 13(4), 305-331. http://dx.doi.org/10.1016/02784254(94)90002-7

Morris, R., Gray, S., Pickering, J., \& Aisbitt, S. (2014). Preparers' Perceptions of the Costs and Benefits of IFRS: Evidence from Australia's Implementation Experience. Accounting Horizons, 28(1), 143-173. http://dx.doi.org/10.2308/acch-50609

Naciri, A., \& Hoarau, C. (2001). A Comparative Analysis of American and French Financial Reporting Philosophies: The Case for International Accounting Standards. Advances In International Accounting, 14, 229-247. http://dx.doi.org/10.1016/s0897-3660(01)14012-2

Nobes, C. (1998). Towards a General Model of the Reasons for International Differences in Financial Reporting. Abacus, 34(2), 162-187. http://dx.doi.org/10.1111/1467-6281.00028

Nobes, C., \& Parker, R. (2008). Comparative International Accounting (10th ed.). Prentice Hall.

Paananen, M., \& Lin, H. (2009). The Development of Accounting Quality of IAS and IFRS over Time: The Case of Germany. Journal Of International Accounting Research, 8(1), 3155. http://dx.doi.org/10.2308/jiar.2009.8.1.31

Piot, C., Janin, R., \& Dumontier, P. (2010) IFRS Consequences on Accounting Conservatism within Europe. SSRN Electronic Journal. http://dx.doi.org/10.2139/ssrn.1724635

Prather-Kinsey, J., Jermakowicz, E., \& Vongphanith, T. (2008). Capital market consequences of European firms' mandatory adoption IFRS. Working Paper, University of Missouri, Tennessee State University.

Qiang, X. (2007). The Effects of Contracting, Litigation, Regulation, and Tax Costs on 


\section{Macrothink}

International Journal of Accounting and Financial Reporting

ISSN 2162-3082

2016, Vol. 6, No. 1

Conditional and Unconditional Conservatism: Cross-Sectional Evidence at the Firm Level. The Accounting Review, 82(3), 759-796. http://dx.doi.org/10.2308/accr.2007.82.3.759

Raffournier, B. (2007). Les oppositions françaises à l'adoption des IFRS : examen critique et tentative d'explication. Comptabilité - Contrôle - Audit, 13(3), 21. http://dx.doi.org/10.3917/cca.133.0021

Soderstrom, N., \& Sun, K. (2007). IFRS Adoption and Accounting Quality: A Review. European Accounting Review, 16(4), 675-702. http://dx.doi.org/10.1080/09638180701706732

Sterling, R. (1967). Conservatism: The Fundamental Principle of Valuation in Traditional Accounting. Abacus, 3(2), 109-132. http://dx.doi.org/10.1111/j.1467-6281.1967.tb00375.x

Watts, R. (2003). Conservatism in Accounting Part I: Explanations and Implications. Accounting Horizons, 17(3), 207-221. http://dx.doi.org/10.2308/acch.2003.17.3.207

Watts, R. (2003). Conservatism in Accounting Part II: Evidence and Research Opportunities. Accounting Horizons, 17(4), 287-301. http://dx.doi.org/10.2308/acch.2003.17.4.287

Zeghal, D., Chtourou, S., \& Fourati, Y. (2012). The Effect of Mandatory Adoption of IFRS on Earnings Quality: Evidence from the European Union. Journal Of International Accounting Research, 11(2), 1-25. http://dx.doi.org/10.2308/jiar-10221

Zeghal, D., Chtourou, S., \& Sellami, Y. (2011). An analysis of the effect of mandatory adoption of IAS/IFRS on earnings management. Journal Of International Accounting, Auditing And Taxation, 20(2), 61-72. http://dx.doi.org/10.1016/j.intaccaudtax.2011.06.001

Zhuang, Z., \& Young., D. (2014). Mandatory IFRS adoption and accounting conservatism. European Accounting Association, Annual meeting.

\section{Copyright Disclaimer}

Copyright for this article is retained by the author(s), with first publication rights granted to the journal.

This is an open-access article distributed under the terms and conditions of the Creative Commons Attribution license (http://creativecommons.org/licenses/by/3.0/). 